\title{
Audit Quality and Earnings Management: Evidence from Portugal
}

\author{
By Ana Paula Lopes*
}

Accounting manipulation is a current problem, reported in many different contexts. Several audit quality studies indicate that there is a relationship between the quality of the audit and the manipulation of the results. These also show that accruals reduce when the auditor is independent or the audit company is large, and suggest that Big 4 Audit Firms present higher levels of audit quality, when compared with other companies. The aim of this paper is to examine if there is a relationship between the manipulation of results and the quality of the audit, based on the study of the behavior of discretionary accruals in Portuguese non-listed companies. Collected on the SABI (Iberian Balance sheet Analysis System) database, the sample is composed of 4723 companies from 2013 to 2015. The empirical model of this study consists of a multiple linear regression in order to explain the relationship between the discretionary accruals and the firm size, debt, volume business and profitability, based on the Modified Jones Model. The results suggest that there is a relationship between audit quality and earnings manipulation. The level of earnings management is significantly lower among companies contracting a Big 4 audit firm, as compared to companies using a non-Big 4 audit firm.

Keywords: Audit Quality, Discretionary Accruals, Earnings Management, Audit Firm Size (Big 4 or non-Big 4)

\section{Introduction}

In the last decades, companies and investors have been exploring investment opportunities, largely due to the globalization of capital markets, international cooperation among countries and increased international trade. The impact of globalization on the world economy brought changes in companies, which faced new challenges and constraints since markets are broader, more volatile and competitive. The constant evolution of markets and aggressive competition motivates managers to use manipulation practices to influence accounting results in order to reflect a better picture of the economic and financial situation of companies. Generally, this is achieved by taking advantage of the flexibility of accounting standards, or even by non-compliance, by modifying financial information.

With the emergence of financial scandals from a number of companies, such as Enron, Adelphia, Global Crossing, Xerox and WorldCom in the United States and Ahold, Adecco and Parmalat in Europe, the independence of the auditor, the role of the external auditor in the company and consequently the quality of the audit were called into question (Bekiris and Doukakis 2011). For

* Associate Professor at Institute of Accounting and Administration of Porto (ISCAP)/Polytechnic of Porto, Portugal. 
the external auditor, an independent body that issues opinions on accountability documents and on which users rely for decision-making, there is an increased need for independent audits of financial statements that inspire confidence and guarantee the reliability of financial information.

In response to these needs, there are studies that warn of risk behaviors and their motivations that lead to these deviant attitudes on the part of managers and administrators by causing accounting fraud, with consequences not only for the company itself, but also for potential investors and other stakeholders (AlRassas and Kamardin 2016, Becker et al. 1998, Hsu and Wen 2015, Tsipouridou and Spathis 2012). Such studies have contributed to understanding the nature, purpose, and implications of earnings management, which may be acceptable through the flexibility of accounting rules. These permit the adoption of accounting policies that allow managers to anticipate or delay the results in the desired direction, without breaking accounting law.

This problem was also studied by some researchers in Portugal (Mendes and Rodrigues 2006, Moreira 2006, Marques et al. 2011). However, there is still a long way to go in studying this subject. Current concerns about restoring investor confidence require greater transparency of financial reporting and reinforcement of the role of stakeholders in the corporate accountability process, which fits the role of the auditor. According to Choi et al. (2010), the quality of auditing is fundamental to the confidence of the capital market players and the economic development of countries. It is therefore important to analyze whether the audit is effective in detecting practices for manipulating the results and conveys them in the audit reports.

The aim of this investigation is to study if there is a relationship between the manipulation of accounting results and audit quality in a group of Portuguese nonlisted companies. The intuition underlying the present study, according to the empirical evidence mentioned in developed countries, is that the size of the audit firm is clearly related to the quality of the audit, suggesting that larger audit firms provide higher quality (DeAngelo 1981, Zhou and Elder 2001, Bauwhede et al. 2003, Krishnan 2003, Yaşar 2013). An auditor who represents one of the four large audit firms, Big 4 (Deloitte Touche Tohmatsu, Ernst \& Young, KPMG and PricewaterhouseCoopers), is able to provide greater audits compared to smaller audit firms.

The remainder of the paper proceeds as follows: Section "Literature Review" reviews the prior literature on earnings management. Section "Methodology" describes the research methodology. Section "Results" presents our major findings and we conclude the paper with Section "Conclusions".

\section{Literature Review}

\section{Earnings Management}

According to Healy and Wahlen (1999), earnings management takes place when managers use judgment in financial reporting and in structuring transactions 
to modify financial reports to either mislead some stakeholders about the underlying economic performance of the company or to influence contractual outcomes that depend on reported accounting numbers. Thus, this definition points to management as the faction responsible for making those decisions that fall under the general management of earnings. But there are two weak points in this definition: it does not establish a distinct limit between earnings management and normal activities, the result of which is earnings; not all earnings management is deceptive.

Ronen and Yaari (2011) define earnings management as a set of managerial decisions that result in not reporting the true short-term, value-maximizing earnings as known to management. In their opinion, earnings management can be: Beneficial - it signals long-term value; Pernicious - it conceals short- or long-term value and Neutral - it reveals the short-term true performance. The managed earnings follow as the consequence of taking production/investment actions earlier than earnings are realized.

Ronen and Yaari (2008) also organize the different definitions of earnings management in three groups: white, gray or black. White earnings management Beneficial - enhances the transparency of reports; Black earnings management Pernicious - involves complete misrepresentation and fraud; Gray earnings management - Gray - includes manipulation of reports in the boundaries of compliance with bright-line standards, which could be either opportunistic or efficiency enhancing.

There are also other authors that define white, gray and black earnings management. White earnings management takes advantage of flexibility in the choice of accounting treatments to signal the manager's private information on future cash flows (Demski et al. 1984, Suh 1990, Demski 1998, Beneish 2001, Sankar and Subramanyam 2001). Gray earnings management chooses an accounting treatment that is either opportunistic or economically efficient (Fields et al. 2001, Scott 2006). Finally, black earnings management is the practice of using tricks to misrepresent or reduce the financial reports transparency (Levitt 1998, Healy and Wahlen 1999, Chtourou and Bedard 2001).

It seems easy to distinguish earnings management, but in reality it is hard since there are accounting transactions where ethical principles and value judgments are crucial in the decision to be taken.

\section{Earnings Management Measurement}

Many authors have used different methods in order to study why and how managers manipulate the results. It is not easy to recognize, identify and measure the earnings management (Dechow and Skinner 2000). Earnings management is typically studied using discretionary accruals (Ahmed et al. 2013). Quite a lot of authors consider that discretionary accruals manipulation is the most usual method of manipulation since it is less expensive and not easily identified by the market (Healy and Palepu, 1993). Furthermore, because of the subjective nature of the judgments involved, it is more difficult to audit (Spathis et al. 2002). 
Usually, it is used the analysis of accruals when we are trying to detect evidence of manipulation, either in specific studies of earnings management (Jones, 1991), or when we are studying the quality of results (Burgstahler et al. 2006). The model of Jones (1991) and the modified model of Jones proposed by Dechow et al. (1995) are the most used models in studies that apply the aggregate (Bartov et al. 2000, Davidson et al. 2005, Bergstresser and Philippon 2006, Gore et al. 2007, Algharaballi and Albuloushi 2008, Jones et al. 2008, Rusmin 2010, Islam et al. 2011, Ecker et al. 2013). In this model accruals may be decomposed into discretionary and non-discretionary accruals.

Even though quite a few models based on accruals had been developed, the solution initially proposed by Jones remains the basis of detection of earnings management.

\section{Methodology}

Some studies (DeAngelo 1981, Becker et al. 1998, Francis et al. 1999) that analyze the quality of the audit, focus on the perspective that technical competence and degree of independence are characteristics that can be observed by the size of the company with incentives to maintain the number of clients and their reputation. Thus, a better quality audit is expected to be associated with lower levels of manipulation of results. In this way, it will be expected that specialized auditors representing reputable companies, particularly Big 4, tend to constrain the manipulation of results to a greater degree compared to lower quality auditors. The implicit idea of such a relationship is summarized in the following investigation hypothesis:

H1: Portuguese non-listed companies audited by Big 4 are more likely to have lower levels of manipulation of results compared to companies audited by non-Big 4.

The sample used in the present investigation consists of Portuguese nonlisted companies, whose financial statements were prepared according to the Accounting Standardization System (SNC) and audited in the scope of a statutory audit available in the SABI (Iberian Balance sheet Analysis System) database for the period between 2011 and 2013 (3 years), is composed by 4723 companies, of 43 industry sectors (Table 1). The option for non-listed companies was supported by the approach to the Portuguese business fabric, composed essentially of small and medium enterprises (SMEs), thus providing a greater number of data for analysis. 
Table 1. Composition of the Sample by a Sector of Activity and Auditor Type

\begin{tabular}{|c|ccc|cc|cc|}
\hline \multirow{2}{*}{ Sectors of Activity } & \multicolumn{5}{|c|}{ Number of Observations } \\
\cline { 2 - 7 } & Big 4 Auditor & Non- Big 4 & \multicolumn{3}{|c|}{ Total } \\
\hline $\begin{array}{c}\text { Agriculture, hunting, } \\
\text { animal production }\end{array}$ & 22 & $3 \%$ & 252 & $6 \%$ & 274 & $6 \%$ \\
\hline Extraction industries & 9 & $1 \%$ & 57 & $1 \%$ & 66 & $1 \%$ \\
\hline Manufacturing & 272 & $34 \%$ & 1618 & $41 \%$ & 1890 & $40 \%$ \\
\hline $\begin{array}{c}\text { Collection, treatment and distribution of } \\
\text { water; sanitation, waste management and } \\
\text { depollution }\end{array}$ & 77 & $10 \%$ & 57 & $1 \%$ & 134 & $3 \%$ \\
\hline Construction & 53 & $7 \%$ & 571 & $15 \%$ & 624 & $13 \%$ \\
\hline $\begin{array}{c}\text { Wholesale and retail trade; repair of } \\
\text { motor vehicles }\end{array}$ & 52 & $7 \%$ & 213 & $5 \%$ & 265 & $6 \%$ \\
\hline Transport and storage & 66 & $8 \%$ & 250 & $6 \%$ & 316 & $7 \%$ \\
\hline Accommodation and catering & 33 & $4 \%$ & 262 & $7 \%$ & 295 & $6 \%$ \\
\hline Information and communication activities & 65 & $8 \%$ & 150 & $4 \%$ & 215 & $5 \%$ \\
\hline Consulting, scientific, technical activities & 64 & $8 \%$ & 291 & $7 \%$ & 355 & $8 \%$ \\
\hline Education & 3 & $0 \%$ & 68 & $2 \%$ & 71 & $2 \%$ \\
\hline Human health activities and social support & 58 & $7 \%$ & 107 & $3 \%$ & 165 & $3 \%$ \\
\hline Artistic and sports activities & 16 & $2 \%$ & 37 & $1 \%$ & 53 & $1 \%$ \\
\hline TOTAL & 790 & $17 \%$ & 3933 & $83 \%$ & 4723 & $100 \%$ \\
\hline
\end{tabular}

Source: Author, adapted from data from SABI

Accrual based tests of earnings management are based on the following linear model:

$$
\mathrm{DA}_{\mathrm{i}, \mathrm{t}}=a+b \mathrm{PART}_{\mathrm{i}, \mathrm{t}}+\varepsilon_{\mathrm{i}, \mathrm{t}}
$$

where,

DA $=$ discretionary accruals; and

PART $=$ a dummy variable that is set to 1 in periods during which a hypothesized determinant of earnings management is present and 0 otherwise.

The empirical model of this study consists of a multiple linear regression in order to explain the relationship between the dependent variable (explained) and the independent (explanatory) variables. The discretionary accruals (DA) are used as a dependent variable, and as independent variables the binary variable that defines whether the company is audited by a Big 4, the size of the company, the indebtedness, the turnover and the profitability.

To test the research hypothesis, we estimate the following model, identified in equation (2), which connects the magnitude of the discretionary accruals with 
the variable of interest, that is, the Big 4 binary variable and the other control variables:

$\mathrm{DA}=\beta_{0}+\beta_{1}$ Big ${ }_{\text {it }}+\beta_{2} \mathrm{DIM}_{\text {it }}+\beta_{3} \mathrm{END}_{\text {it }}+\beta_{4} \mathrm{CRES}_{\text {it }}+\beta_{5} \mathrm{REND}_{\text {it }}+\varepsilon_{\text {it }}$

where,

Big 4 - Binary or dummy variable that has value "1" if a company is audited by a Big 4 and takes a value "0" otherwise. This variable allows differentiating the audit quality.

According to DeAngelo (1981), Big 4 audit firms are more likely to conduct higher quality audits because they care about maintaining a good reputation in the market, and their auditors are sometimes subject to disciplinary sanctions. The authors (Tendeloo and Vanstraelen 2008) also prove this argument, since they say that companies audited by a Big 4 have lower levels of manipulation of results, compared to companies that are not audited by a Big 4. According to Becker et al. (1998), it is expected that the variable "Big 4" will present a negative signal.

DIM - Measures the size of the company, through the total asset logarithm. This variable is considered a determinant in the manipulation of results and in the level of accruals, because according to the studies carried out by Tendeloo and Vanstraelen (2008) there is a relation between the dimension and the manipulation of results. Boone et al. (2010) concluded that the larger the size of companies, the lower the manipulation of results. Thus, the coefficient associated with this variable $\left(\beta_{2}\right)$ is expected to present a negative signal.

END - This variable measures the company's level of indebtedness. It is calculated by the ratio of total liabilities to total net assets.

This variable can influence the manipulation of results and therefore the quality of the results through two processes. On the one hand, the empirical evidence shows that the existence of high debts in companies with financial difficulties leads to a growing manipulation of results to avoid non-compliance with the constraints imposed by the financing agreements (Tendeloo and Vanstraelen 2008). On the other hand, the debt is also a motivation for the quality of the audit, suggesting that for higher levels of indebtedness, there may be less tendency to manipulate results due to contractual renegotiations and because there is a greater control by creditor entities (Becker et al. 1998, Van Tendeloo $\&$ Vanstraelen 2008). Thus, considering the presence of forces of opposite direction, no expectation is expressed as to the expected signal for the coefficient of the variable "END" of the model (2).

CRES - The variable "CRES" represents the annual percentage growth of sales consisting of the ratio between the annual variation of sales and the sales of year $\mathrm{t}-1$.

This variable intends to control differences in company performance. A sign of the positive coefficient of the variable "CRES" $\left(\beta_{4}\right)$ is expected, since this variable is expected to contribute to an increase in the manipulation of results 
(Tendeloo and Vanstraelen 2008, Boone et al. 2010), which shows that companies with higher growth are encouraged to manipulate results.

REND - Measures the operating return on assets (ROA) by the ratio of Operating Income and Net Assets Total, showing how the company's assets influence the match-fixing.

This variable was shown to be significant in studies whose purpose is the quality of financial reporting. According to Tendeloo and Vanstraelen (2008), this variable is also a way to control performance differences, according to these, the companies with greater profitability of the assets, are involved less in results management.

There is evidence that companies with lower profitability availing match-fixing practices, with a view to providing a controlled decline of idea, which would not occur if there was a high variability of these performances, an increased risk and loss of confidence in the management. Thus, it is expected that the companies with higher operating profitability of the assets, have a lower incentive to manipulate results, and therefore we predict a negative relation with this practice.

\section{Results}

\section{Descriptive Statistics}

In order to characterize our sample, this section will analyze and comment on the descriptive statistics of the sample. For the accomplishment of the statistical tests and of the regressions was used the program IBM SPSS Statistics 21 . To verify the assumption of normality, as we are dealing with a large sample, $\mathrm{N}=4723$, by the central limit theorem we can assume that violation of this assumption does not call into question the study. Some descriptive statistics of the sample are presented in Table 2.

Table 2. Descriptive Statistics of the Sample

\begin{tabular}{|c|c|c|c|c|}
\hline Variable & Observations & Mean & Median & Standard Deviation \\
\hline DA & 4723 & 0,052713 & 0,046562 & 0,034287 \\
\hline DIM & 4723 & 6,831057 & 6,789632 & 0,636458 \\
\hline END & 4723 & 0,663901 & 0,676888 & 0,178933 \\
\hline CRES & 4723 & 0,015177 & 0,002985 & 0,126065 \\
\hline REND & 4723 & 0,028632 & 0,027925 & 0,110089 \\
\hline
\end{tabular}

Source: Author, adapted from data from SABI

From the analysis of the descriptive statistics measures we highlight the following aspects: 
- The quality measure of discretionary accruals "DA" of the companies that compose our sample takes on average the value of 0.053 , median the value of 0.047 and standard deviation 0.034 . These values do not present great differences, which demonstrate a normal distribution of the sample, evidencing non-dispersion of the data.

- In average terms, the companies have a level of indebtedness (END) of around $66.4 \%$, annual sales growth (CRES) of $1.5 \%$ and a REND of close to $3 \%$.

- We can observe that the variables "DIM" and "CRES", have the highest and lowest value, respectively, relative to the average value.

Some of its statistical characteristics will also be discussed, in particular, the absence of multicollinearity between the variables, that is, the lack of correlation between the variables of the model under study. The Pearson correlation coefficients will be presented for the variables of the model under study. Table 3 shows the correlation between the variables of the multivariate model defined for our study. Through Pearson's correlation coefficients, we can analyze the correlations between the different variables of the model.

Table 3. Correlation Coefficients

\begin{tabular}{|c|c|c|c|c|c|c|}
\hline & Big 4 & DA & DIM & END & CRES & REND \\
\hline Big 4 & 1 & & & & & \\
\hline DA & 0,083 & 1 & & & & \\
\hline DIM & 0,194 & $-0,057$ & 1 & & & \\
\hline END & $-0,001$ & $-0,048$ & $-0,036$ & 1 & & \\
\hline CRES & $-0,035$ & 0,061 & $-0,102$ & 0,103 & 1 & \\
\hline REND & 0,047 & 0,086 & $-0,104$ & $-0,242$ & 0,101 & 1 \\
\hline
\end{tabular}

Source: Author, adapted from data from SABI

According to Gujarati (2004), a correlation coefficient between two variables that in absolute value is superior to 0,8 , reveals the existence of serious problems of multicollinearity. However, this criterion should be used carefully and weighted for each specific case, usually conservatively, values greater than 0.4 will be avoided.

By the observation of the coefficients presented in Table 3, they suggest a low multicollinearity among the variables of the model under analysis, since the correlation coefficients present low values, removing the hypothesis of existence of multicollinearity problems in the estimation of the model. Thus, in general, it can be said that all variables have a weak correlation with each other. The higher correlation (approximately -0.242), between the "END" and "REND" variables, suggests that more indebted companies have lower profitability levels.

The dependent variable "DA" is significantly and positively correlated with the variables "Big 4", "CRES" and "REND" and negatively with the variables "Dimension" and "END". These results suggest that companies audited by a Big 4, with a higher level of sales growth and greater profitability, smaller and less 
indebted, are associated with a greater magnitude of the discretionary accruals and as such to a bigger manipulation of results.

All variables present statistically significant correlations, except for the correlation between Big 4 and NDT, which was not statistically significant. Next, we will analyze the empirical evidence obtained with the estimation of the model under study. Table 4 presents the results of the estimation of the model (equation (2)). This is statistically significant, and its explanatory power has an adjusted $\mathrm{R}^{2}$ of $24.3 \%$.

It can be verified that the generality of the variables presents coefficients with the signal concordant with the expectations discussed.

Table 4. Results of the Regression Model

\begin{tabular}{|c|c|c|c|}
\hline Variables & Expected Signal & Coefficient & P-Value \\
\hline Constant & & 0,041 & 0,000 \\
\hline Big 4 & - & $-0,001$ & 0,000 \\
\hline DIM & - & $-0,002$ & 0,000 \\
\hline END & $?$ & 0,003 & 0,132 \\
\hline CRES & + & 0,024 & 0,000 \\
\hline REND & - & 0,001 & 0,004 \\
\hline Observations & 4723 & \\
\hline F test & 0,000 & \\
\hline Adjusted R & 0,243
\end{tabular}

Source: Author, adapted from data from SABI

Let us now analyze in more detail all the variables and their impact on the explanation of discretionary accruals.

The variable "Big 4" is statistically significant to explain the behavior of discretionary accruals ( $p$-value $=, 000$ ) with its coefficient of -0.001 , which means that Big 4 audits work as a constraint to the manipulation of results. The expected coefficient of -0.001 for the variable "Big 4 " means that the magnitude of the discretionary accruals decreases by $0.1 \%$ if the Big 4 value grows from 0 to 1 . That is, if it is audited by a non Big 4 company, the variable "DA" has the approximate average value of 0.041 , if audited by a Big 4 assumes the value 0.041-0.001. The value for this coefficient is consistent with those obtained in the literature (Becker et al. 1998, Francis et al. 1999).

The "DIM" variable has a coefficient of -0.002 and is statistically significant (p-value $=, 000)$, which means that the larger the company size the lower its level of results manipulation, thus presenting a better quality of the financial report. Our result is consistent with those obtained by (Tendeloo and Vanstraelen 2008) and (Boone et al. 2010), both found a negative association between the size of the company and the manipulation of results.

The variable "END" presents a coefficient of 0.003 and is not statistically significant ( $\mathrm{p}$-value $=, 132$ ), thus observing the assumption that the levels of indebtedness would be one of the main motivations for the manipulation of results. The sign of the coefficient of this variable reflects the idea that the 
higher the level of indebtedness of the company, the greater the concern of the company to present results that allow more favorable contractual conditions (Tendeloo and Vanstraelen 2008, Becker et al. 1998).

The variable "CRES" is statistically significant ( $\mathrm{p}$-value $=, 000)$ and with a coefficient of 0.024 , suggesting that companies with higher growth lead to greater practice of manipulation of results. This study is in line with what was expected (Tendeloo and Vanstraelen 2008, Boone et al. 2010).

The variable "REND" is significant ( $\mathrm{p}$-value $=, 004$ ) with a coefficient of 0.001 , which indicates that the operating profitability of the assets is positively associated with discretionary accruals. Thus, the $1 \%$ variation in the operating profitability of the assets results in a variation of -0.001 in the absolute value of the discretionary accruals. The sign of this variable is contrary to expectations. It is not consistent with other studies that concern the quality of financial reporting, such as that done by Romanus et al. (2008). We can thus conclude that the control variables are all statistically significant except for the variable "END" (p-value $=0.132$ ). According to these results, nothing tells us that levels of indebtedness can be associated with the level of quality of the results of the companies under analysis.

The adjusted $\mathrm{R}^{2}$ value, presented in Table 4 , indicates that the discretionary accruals (DA) variation can be explained in around $24.3 \%$ around its mean by the independent variables inserted in the model. It is set aside, since the p-value of the F-statistic (p-value $=0.000$ ) is lower than all the usual levels of significance $(1 \%, 5 \%, 10 \%)$, which means that the model is valid for explaining the variation in the quality of discretionary accruals.

\section{Conclusions}

In this empirical study the objective was to analyze the existence of a relationship between the manipulation of results and the quality of the audit in Portuguese non-listed companies, because it is an issue that has not yet been explored in this type of companies. For this, we used the methodological construction derived from the Ball and Shivakumar (2006) model, which reprocessed the Jones (1991) and Dechow and Dichev (2002) models and the association between adjustments resulting from the accrual basis and the cash flow (Ball and Shivakumar 2005), adding independent variables as proxies for economic losses, establishing several assumptions.

Based on a sample of 4723 Portuguese non-listed companies, withdrawn from the SABI database between 2011 and 2013, comprising 790 companies audited by a Big 4 (17\% of the total sample) and 3933 companies audited by a non-Big 4 (83\% of the total sample), it was tested whether firms audited by Big 4 are more likely to have lower levels of manipulation of results than firms audited by non-Big 4 s.

The empirical evidence obtained corroborated the hypothesis formulated. The main empirical results show a relationship between the manipulation of results and the quality of the audit, suggesting that companies audited by a Big 
4 have a lower degree of manipulation of results than companies that are audited by a non-Big 4 . Our results are consistent with the results obtained by others (Tendeloo and Vanstraelen 2008, Boone et al. 2010), where they concluded that in countries with low fiscal alignment, companies audited by a Big 4 firm are more involved in manipulating results when compared to companies audited by a non-Big 4 .

We also conclude that companies audited by a Big 4 firm, with higher levels of annual sales growth and higher profitability and smaller and less indebted, are associated with a greater magnitude of discretionary accruals and, as such, more manipulation of results. This study also reveals that the larger the size of unlisted companies, the greater the practice of results management in order to increase them. On the other hand, in the presence of low profits, companies show a lower tendency to practice results management and evidence to manage more the results in the direction of their increase.

This research is particularly relevant from the point of view of academic research because it is applied to the Portuguese context and contributes to the literature on the manipulation of results and its relation to the quality of the audit.

\section{References}

Ahmed K, Chalmers K, Khlif H (2013) A Meta-analysis of IFRS adoption effects. International Journal of Accounting 48(2): 173-217. doi: 10.1016/j.intacc.2013. 04.002 .

Al-Rassas AH, Kamardin H (2016) Earnings quality and audit attributes in high concentrated ownership market. Corporate Governance: The international journal of business in society 16(2): 377-399. doi: 10.1108/CG-08-2015-0110.

Algharaballi E, Albuloushi S (2008) Evaluating the specification and power of discretionary accruals models in Kuwait. Journal of Derivatives \& Hedge Funds 14(3/4): 251-264. doi: 10.1057/jdhf.2008.23.

Ball R, Shivakumar L (2005) Earnings quality in UK private firms: Comparative loss recognition timeliness, Journal of Accounting and Economics 39(1): 83-128. doi: 10.1016/j.jacceco.2004.04.001.

Ball R, Shivakumar L (2006) The role of accruals in asymmetrically timely gain and loss recognition. Journal of Accounting Research 44(2): 207-242. doi: 10.1111/j.1475679X.2006.00198.x.

Bartov E, Gul FA, Tsui JSL (2000) Discretionary-accruals models and audit qualifications. Journal of Accounting and Economics 30(3): 421-452. doi: 10.1016/ S0165-4101(01)00015-5.

Bauwhede H, Willekens M, Gaeremynck A (2003) Audit firm size, public ownership, and firms' discretionary accruals management. International Journal of Accounting 38(1): 1-22. doi: 10.1016/S0020-7063(03)00004-9.

Becker CL et al. (1998) The Effect of Audit Quality on Earnings Management. Contemporary Accounting Research 15(1): 1-24. doi: 10.1111/j.1911-3846.1998.tb 00547.x.

Bekiris FV, Doukakis LC (2011) Corporate Governance and Accruals Earnings Management. Managerial and Decision Economics 32(7): 439-456. doi: 10.1002/ mde.1541. 
Beneish MD (2001) Earnings management: a perspective. Managerial Finance 27(12): 317. doi: $10.1108 / 03074350110767411$.

Bergstresser D, Philippon T (2006) CEO incentives and earnings management. Journal of Financial Economics 80(3): 511-529. doi: 10.1016/j.jfineco.2004.10.011.

Boone JP, Khurana IK, Raman KK (2010) Do the Big 4 and the Second-tier firms provide audits of similar quality? Journal of Accounting and Public Policy 29(4): 330-352. doi: 10.1016/j.jaccpubpol.2010.06.007.

Burgstahler DC et al (2006) The Importance of Reporting Incentives: Earnings Management in European Private and The Importance of Reporting Incentives: Earnings Management in European Private and Public Firms. Source: The Accounting Review, 81(5): 983-1016. doi: 10.2308/accr.2006.81.5.983.

Choi JH et al (2010) Audit office size, audit quality, and audit pricing. Auditing, 29(1): 73-97. doi: 10.2308/aud.2010.29.1.73.

Chtourou SM, Bedard J (2001) Corporate Governance and Earnings Management. Social Science Research Network (SSRN) 4(418): 1-39. doi: 10.2139/ssrn.275053.

Davidson R, Goodwin-Stewart J, Kent P (2005) Internal governance structures and earnings management. Accounting and Finance 45(2): 241-267. doi: 10.1111/j.1467629x.2004.00132.x.

DeAngelo LE (1981) Auditor size and audit quality. Journal of Accounting and Economics 3(3): 183-199. doi: 10.1016/0165-4101(81)90002-1.

Dechow PM, Dichev ID (2002) The quality of accruals and earnings: The role of accrual estimation errors. Accounting Review 77: 35-59. doi: 10.2308/accr.2002.77.s-1.61.

Dechow PM, Skinner DJ (2000) Earnings management: Reconciling the views of accounting academics, practitioners, and regulators. Accounting Horizons 14(2): 235-250. doi: 10.2308/acch.2000.14.2.235.

Dechow PM, Sloan RG, Sweeney AP (1995) Detecting Earnings Management. The Accounting Review 70(2): 193-225. doi: 10.2307/248303.

Demski JS (1998) Performance Measure Manipulation. Contemporary Accounting Research 15(3): 261-285. doi: 10.1111/j.1911-3846.1998.tb00560.x.

Demski JS, Patell JM, Wolfson Ma (1984) Decentralized Choice of Monitoring Systems. Accounting Review 59(1): 16-34. Retrieved from: http://bit.ly/2jzNWtd.

Ecker $\mathrm{F}$ et al. (2013) Estimation sample selection for discretionary accruals models. Journal of Accounting and Economics 56(2-3): 190-211. doi: 10.1016/j.jacceco. 2013.07.001.

Fields TD, Lys TZ, Vincent L (2001) Empirical research on accounting choice. Journal of Accounting \& Economics 31(1-3): 255-307. doi: 10.1016/S0165-4101(01)00028-3.

Francis JR, Maydew EL, Sparks HC (1999) The role of Big 6 auditors in the credible reporting of accruals. Auditing 18(2): 17-34. doi: 10.2308/aud.1999.18.2.17.

Gore P, Pope PF, Singh AK (2007) Earnings management and the distribution of earnings relative to targets: UK evidence. Accounting and Business Research 37(2): 123129,134,136,138. doi: 10.1080/00014788.2007.9730065.

Gujarati DN (2004) Basic Econometrics. New York: McGraw-Hill Education. doi: 10.1126/science. 1186874.

Healy PM, Palepu K. G (1993) The Effect of Firms' Financial Disclosure Strategies on Stock Prices. Accounting Horizons 7(1): 1-11.

Healy PM, Wahlen, JM (1999) A review of the earnings management literature and its implications for standard setting. Accounting Horizons 13(4): 365-383. doi: 10.2308/ acch.1999.13.4.365.

Hsu MF, Wen SY (2015) The Influence of Corporate Governance in Chinese Companies on Discretionary Accruals and Real Earnings Management. Asian Economic and Financial Review 5(3): 391-406. doi: 10.18488/journal.aefr/2015.5.3/102.3.391.406. 
Islam MA, Ali R, Ahmad Z (2011) Is Modified Jones Model Effective in Detecting Earnings Management? Evidence from A Developing Economy. International Journal of Economics and Finance 3(2). doi: 10.5539/ijef.v3n2p116.

Jones JJ (1991) Earnings Management During Import Relief Investigations. Journal of Accounting Research 29(2): 193. doi: 10.2307/2491047.

Jones KL, Krishnan GV, Melendrez KD (2008) Do Models of Discretionary Accruals Detect Actual Cases of Fraudulent and Restated Earnings? An Empirical Analysis. Contemporary Accounting Research 25(2): 499-531. doi: 10.1506/car.25.2.8.

Krishnan GV (2003) Does big 6 auditor industry expertise constrain earnings management? Accounting Horizons (1-16). doi: 10.2308/acch.2003.17.s-1.1.

Levitt A (1998) The Numbers Game. Remarks by Chairman Arthur Levitt at the NYU Center for Law and Business. Retrieved from https://www.sec.gov/news/speech/ speecharchive/1998/spch220.txt.

Marques M, Rodrigues LL, Craig R (2011) Earnings management induced by tax planning: The case of Portuguese private firms. Journal of International Accounting, Auditing and Taxation 20(2): 83-96. doi: 10.1016/j.intaccaudtax.2011.06.003.

Mendes C, Rodrigues L (2006) Estudo de práticas de earnings management nas empresas portuguesas cotadas em bolsa: Identificação de alisamento de resultados e seus factores explicativos. Revista de Estudos Politécnicos 145-173.

Moreira JAC (2006) Manipulação para evitar perdas: o impacto do conservantismo. Contabilidade e Gestão, Revista Cientifica da Câmara 3: 33-63. Retrieved from: http://bit.ly/2BE6YWC.

Romanus RN, Maher JJ, Fleming DM (2008) Auditor industry specialization, auditor changes, and accounting restatements. Accounting Horizons 22(4): 389-413. doi: 10.2308/acch.2008.22.4.389.

Ronen J, Yaari V (2008) Earnings Management: Emerging Insights in Theory, Practice, and Research. New York: Springer. ISBN 978-0-387-25769-3.

Ronen J, Yaari V (2011) Earnings management: Emerging insights in theory, practice and research. The international Journal of accounting 46(2): 236-237. doi: 10.1007/9780-387-25771-6.

Rusmin R (2010) Auditor quality and earnings management: Singaporean evidence. Managerial Auditing Journal 25(7): 618-638. doi: 10.1108/02686901011061324.

Sankar MR, Subramanyam KR (2001) Reporting discretion and private information communication through earnings. Journal of Accounting Research 39(2): 365-386. doi: $10.2307 / 2672961$.

Scott WR (2006) Financial Accounting Theory. Learning p. 546. Available at: http:// books.google.com/books?id=76epLQAACAAJ\&pgis=1.

Spathis C, Doumpos M, Zopounidis C (2002) Detecting falsified financial statements: a comparative study using multicriteria analysis and multivariate statistical techniques. European Accounting Review 11(3): 509-535. doi: 10.1080/0963818022000000966.

Suh YS (1990) Communication and Income Smoothing Through Accounting Method Choice. Management Science 36(6): 704-723. doi: 10.1287/mnsc.36.6.704.

Tendeloo B, Vanstraelen A (2008) Earnings management and audit quality in Europe: Evidence from the private client segment market. European Accounting Review 17(3): 447-469. doi: 10.1080/09638180802016684.

Tsipouridou M, Spathis C (2012) Earnings management and the role of auditors in an unusual IFRS context: The case of Greece. Journal of International Accounting, Auditing and Taxation 21(1): 62-78. doi: 10.1016/j.intaccaudtax.2012.01.005.

Yaşar A (2013) Big four auditors' audit quality and earnings management: Evidence from Turkish stock market. International Journal of Business and Social Science 4(17): 154-163. 
Vol. 4, No. 2 Lopes: Audit Quality and Earnings Management: Evidence from Portugal

Zhou J, Elder R (2001) Audit Firm Size, Industry Specialization and Earnings Management by Initial Public Offering Firms. State University of New York at Binghamton (315). 